\title{
Transfer of radiocaesium from contaminated bottom sediments to marine organisms through benthic food chains in post-Fukushima and post-Chernobyl periods
}

\author{
Roman Bezhenar ${ }^{1}$, Kyung Tae Jung ${ }^{2}$, Vladimir Maderich ${ }^{1}$, Stefan Willemsen ${ }^{3}$, Govert de With ${ }^{3}$, and Fangli Qiao \\ ${ }^{1}$ Institute of Mathematical Machine and System Problems, Glushkov av., 42, Kiev 03187, Ukraine \\ ${ }^{2}$ Korea Institute of Ocean Science and Technology, 787, Haean-ro, Ansan 426-744, Republic of Korea \\ ${ }^{3} \mathrm{NRG}$, Utrechtseweg 310, 6800 ES Arnhem, the Netherlands \\ ${ }^{4}$ First Institute of Oceanography, 6 Xianxialing Road Qingdao 266061, China
}

Correspondence to: Vladimir Maderich (vladmad@gmail.com)

Received: 18 December 2015 - Published in Biogeosciences Discuss.: 18 January 2016

Revised: 21 April 2016 - Accepted: 3 May 2016 - Published: 23 May 2016

\begin{abstract}
After the earthquake and tsunami on 11 March 2011 damaged the Fukushima Dai-ichi Nuclear Power Plant (FDNPP), an accidental release of a large amount of radioactive isotopes into both the air and the ocean occurred. Measurements provided by the Japanese agencies over the past 5 years show that elevated concentrations of ${ }^{137} \mathrm{Cs}$ still remain in sediments, benthic organisms, and demersal fishes in the coastal zone around the FDNPP. These observations indicate that there are ${ }^{137} \mathrm{Cs}$ transfer pathways from bottom sediments to the marine organisms. To describe the transfer quantitatively, the dynamic food chain biological uptake model of radionuclides (BURN) has been extended to include benthic marine organisms. The extended model takes into account both pelagic and benthic marine organisms grouped into several classes based on their trophic level and type of species: phytoplankton, zooplankton, and fishes (two types: piscivorous and non-piscivorous) for the pelagic food chain; deposit-feeding invertebrates, demersal fishes fed by benthic invertebrates, and bottom omnivorous predators for the benthic food chain; crustaceans, mollusks, and coastal predators feeding on both pelagic and benthic organisms. Bottom invertebrates ingest organic parts of bottom sediments with adsorbed radionuclides which then migrate up through the food chain. All organisms take radionuclides directly from water as well as food. The model was implemented into the compartment model POSEIDON-R and applied to the north-western Pacific for the period of 1945-2010, and then for the period of 2011-2020 to assess the radiologi-
\end{abstract}

cal consequences of ${ }^{137} \mathrm{Cs}$ released due to the FDNPP accident. The model simulations for activity concentrations of ${ }^{137} \mathrm{Cs}$ in both pelagic and benthic organisms in the coastal area around the FDNPP agree well with measurements for the period of 2011-2015. The decrease constant in the fitted exponential function of simulated concentration for the deposit-feeding invertebrates $\left(0.45 \mathrm{yr}^{-1}\right)$ is close to the observed decrease constant in sediments $\left(0.44 \mathrm{yr}^{-1}\right)$. These results strongly indicate that the gradual decrease of activity in demersal fish (decrease constant is $0.46 \mathrm{yr}^{-1}$ ) is caused by the transfer of activity from organic matter deposited in bottom sediment through the deposit-feeding invertebrates. The estimated model transfer coefficient from bulk sediment to demersal fish in the model for 2012-2020 (0.13) is larger than that to the deposit-feeding invertebrates (0.07). In addition, the transfer of ${ }^{137} \mathrm{Cs}$ through food webs for the period of 1945-2020 has been modelled for the Baltic Sea contaminated due to global fallout and from the Chernobyl accident. The model simulation results obtained with generic parameters are also in good agreement with available measurements in the Baltic Sea. Unlike the open coastal system where the FDNPP is located, the dynamics of radionuclide transfer in the Baltic Sea reach a quasi-steady state due to the slow rate in water mass exchange in this semi-enclosed basin. Obtained results indicate a substantial contribution of the benthic food chain in the long-term transfer of ${ }^{137} \mathrm{Cs}$ from contaminated bottom sediments to marine organisms and the 
potential application of a generic model in different regions of the world's oceans.

\section{Introduction}

A catastrophic earthquake and tsunami, that occurred on 11 March 2011, severely damaged the Fukushima Dai-ichi Nuclear Power Plant (FDNPP). The loss of power and the subsequent overheating, meltdowns, and hydrogen explosions at the FDNPP site resulted in the uncontrolled release of radioactivity into the air and ocean (Povinec et al., 2013). The atmospheric fallout over the land and the ocean peaked in mid-March whereas the direct release to the ocean from FDNPP peaked in the beginning of April. Approximately $80 \%$ of the radioactivity released due to the accident in MarchApril 2011 was either directly discharged into the ocean or deposited onto the ocean surface from the atmosphere. The concentration of ${ }^{137} \mathrm{Cs}$ in the ocean reached a maximum in mid-April of 2011 and has thereafter declined (by a factor of $10^{5}$ ), except for the area around the FDNPP, where continuous leaks of contaminated water have been reported (Kanda, 2013). However, the concentration of ${ }^{137} \mathrm{Cs}$ in the bottom sediment that was contaminated by water with high concentrations in April-May 2011 remains quite high and is showing signs of very slow decrease with time (Otosaka and Kobayashi, 2013; Kusakabe et al., 2013; Ambe et al., 2014; Black and Buesseler, 2014). The concentration of organically bound ${ }^{137} \mathrm{Cs}$ in coastal areas is several times higher than that of the bulk sediment (Otosaka and Kobayashi, 2013; Ono et al., 2015) due to ${ }^{137} \mathrm{Cs}$ adsorption onto organic matter. It is worth noting that organic matter content in the shelf of Fukushima and Ibaraki prefectures varies in the range of 0.1-25\% (Otosaka and Kobayashi, 2013; Ambe et al., 2014; Ono et al., 2015). The preferential adsorption of ${ }^{137} \mathrm{Cs}$ onto organic matter can be explained by the partial coverage of fine mineral sediment by organic substances and subsequent blocking of sorption (Kim et al., 2006; Ono et al., 2015). Comparison of the concentration of ${ }^{137} \mathrm{Cs}$ in the sediment and benthic invertebrates (Sohtome et al., 2014) and in the demersal fishes (Buesseler et al., 2012; Wada et al., 2013; Tateda et al., 2013) suggests that the continual ingestion of organic matter from sediments can be an important contamination pathway for all components of the benthic food web. However, in most of the benthic food web models applied to the FDNPP accident, the deposit feeding is not included as a transfer mechanism in the food chain (Tateda et al., 2013, 2015, 2016; Keum et al., 2015; Vives i Batlle, 2016; Vives i Batlle et al., 2016).

Several models were used to perform long-term assessments of the radiological impact in the marine environment due to the FDNPP accident (Nakano and Povinec, 2012; Maderich et al., 2014a, b). In particular, the compartment model POSEIDON-R (Maderich et al., 2014a, b) correctly predicted the concentration of ${ }^{137} \mathrm{Cs}$ and ${ }^{90} \mathrm{Sr}$ in water and sediments in the coastal box $(30 \times 15 \mathrm{~km})$ around the FDNPP for 2011-2013. In these studies, the flux of radionuclides due to the groundwater leakage of contaminated waters from FDNPP (Kanda, 2013) was taken into account. However, the version of the dynamic food chain biological uptake model of radionuclides (BURN) coupled to the POSEIDON-R model (Heling et al., 2002; Lepicard et al., 2004; Maderich et al., $2014 a, b)$ did not take into account the benthic food web processes. Notwithstanding, the results of simulations still agreed well with observations for the first months and years when transfer from water was dominant (Maderich et al., 2014a, b). Measurements following the Fukushima Dai-ichi accident suggest that transfer of radioactivity from bottom deposits through the benthic food web over longer timescales can be an increasingly important factor in the radiological assessment of released radioactivity.

Another relevant example is the significant contamination of the Baltic Sea in 1986 by the deposition of activity originating from the Chernobyl accident. Unlike the coastal sea region near FDNPP, the Baltic Sea is a semi-enclosed relatively shallow sea filled by brackish waters and connected with the ocean by the narrow and shallow Danish Straits (Leppäranta and Myrberg, 2009). Within HELCOM (Helsinki Convention on the Protection of the Marine Environment of the Baltic Sea Area, http://www.helcom.fi) the group MORS (Monitoring of Radioactive Substances) established an internationally agreed monitoring network in 1986 and deposited all the data in a common database (MORS, 2015). Therefore, this event also represents a good test case to validate models and study the benthopelagic coupling effects on radionuclide dynamics (Periañez et al., 2015).

In this study, an extended food web model is presented that considers both pelagic and benthic food chains. This dynamic model was implemented into the compartment model POSEIDON-R and applied to the north-western Pacific for the period of 1945-2020 to assess the radiological consequences from the ${ }^{137} \mathrm{Cs}$ released as a result of global fallout and the Fukushima Dai-ichi accident. The model was also applied to the Baltic Sea for the period 1945-2020 to show the applicability of this model to other systems. The paper is organized as follows. Descriptions of the compartment model and the extended dynamic food web model are given in Sect. 2. Section 3 presents the model application and results for the Fukushima Dai-ichi accident. The results of the model application to the Baltic Sea are given in Sect. 4. Section 5 summarizes our findings.

\section{Model description}

In this study, the dynamic model BURN was extended to describe transfer pathways of ${ }^{137} \mathrm{Cs}$ from bottom sediments to marine organisms. The model was developed to assess doses from marine products in the decision-support system 
RODOS for off-site nuclear emergencies (Lepicard et al., 2004). For such aim it was necessary to use a robust and generic model requiring a minimal number of parameters. Therefore, in the model, marine organisms are grouped into a few classes based on trophic levels and types of species. The radionuclides are also grouped in several classes depending on the type of tissues in which a specific radionuclide accumulates preferentially. These simplifications allow for a limited number of standard input parameters. The transfer scheme of radionuclides through the marine food web is shown in Fig. 1 where transfer of radionuclides through the food web is shown by arrows whereas the direct transfer from water is depicted by the shadowed rectangle surrounding 11 biotic compartments $(i=1, \ldots, 11)$. Pelagic organisms are divided into primary producer, phytoplankton $(i=1)$, and consumers which consist of zooplankton $(i=2)$, foraging (non-piscivorous) fish $(i=3)$, and piscivorous fish $(i=4)$. The benthic food web includes three primary pathways for radionuclides: (I) transfer from water to macroalgae $(i=5)$, then to grazing invertebrates $(i=6,7,8)$; (II) transfer through the vertical flux of detritus and zooplankton faeces (Fowler et al., 1987) to detritus-feeding invertebrates $(i=8)$; and (III) transfer through contaminated bottom sediments to deposit-feeding invertebrates $(i=6)$. External boxes in Fig. 1 show the concentrations of radionuclides in water and in the upper layer of bottom sediment calculated using the box model POSEIDON-R described further down. The radionuclides adsorbed on the organic matter in the sediments are bioavailable for benthic organisms but the mineral component of sediments is not (Ueda et al., 1977, 1978). However, Koyanagi et al. (1978) found relatively rapid and more intensive transfer of several sedimentadsorbed radionuclides $\left({ }^{54} \mathrm{Mn},{ }^{60} \mathrm{Co},{ }^{65} \mathrm{Zn}\right)$ to particular organs of the demersal fishes in contrast to flesh. We assume that (i) radioactivity concentrations in organic and mineral fractions of bottom deposit are in mutual equilibrium, (ii) radioactivity concentrations in microbial biota and non-living organic matter also are in equilibrium, and (iii) only organic matter in the bottom deposit is bioavailable. The benthic invertebrate group includes mollusks (e.g. filter feeders) $(i=7)$, crustaceans (e.g. detritus feeders) $(i=8)$, and subsurface and surface deposit feeders (e.g. annelid) $(i=6)$. In the model, radioactivity is transferred from benthic invertebrates to demersal fishes $(i=9)$ that feed on them, and on to omnivorous bottom predators $(i=10)$ (Fig. 1). The marine food web also includes "coastal predators" $(i=11)$ feeding in the whole water column in shallow waters.

In the extended model utilized in this study, the concentration of radioactivity in phytoplankton $C_{1}$ is calculated using the biological concentration factor (BCF) approach due to the rapid uptake from water and the short retention time of radioactivity:

$C_{1}=\mathrm{CF}_{\mathrm{ph}} C_{\mathrm{w}}$,

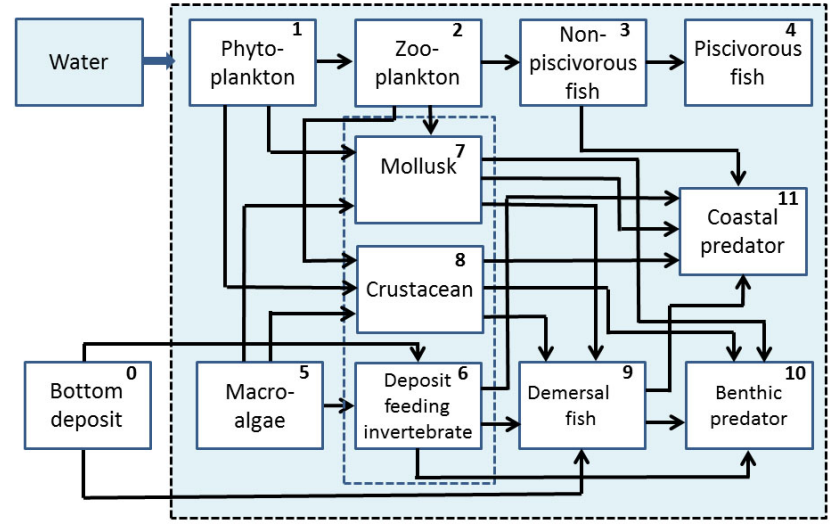

Figure 1. Biological compartments with corresponding numbers (reported in the text and tables) and radionuclide transfer (arrows) for extended dynamic food chain BURN model. Compartments within the shadowed rectangle also exchange radionuclides directly with the surrounding water. The output from the compartment POSEIDON-R model is shown by the external boxes, namely water and bottom deposit.

where $C_{\mathrm{w}}$ is concentration of radioactivity in water and $\mathrm{CF}_{\mathrm{ph}}$ the $\mathrm{BCF}$ for phytoplankton. For the macroalgae, a dynamic model is used to describe radionuclide concentrations due to the longer retention times

$\frac{\mathrm{d} C_{5}}{\mathrm{~d} t}=\left(\mathrm{CF}_{\mathrm{ma}} C_{\mathrm{w}}-C_{5}\right) \ln 2 T_{0.5,5}^{-1}$,

where $C_{5}$ is the concentration of radioactivity in the macroalgae and $\mathrm{CF}_{\mathrm{ma}}$ the corresponding $\mathrm{BCF}, T_{0.5,5}$ is the biological half-life of the radionuclide in the macroalgae, and $t$ is the time. The concentration of a given radionuclide in the zooplankton $(i=2)$, invertebrates $(i=6,7,8)$, and fish $(i=3$, 4, 9, 10, 11; see Table 1 for a description of the different fish groups in the model) is described by the following differential equation:

$\frac{\mathrm{d} C_{i}}{\mathrm{~d} t}=a_{i} K_{\mathrm{f}, i} C_{\mathrm{f}, i}+b_{i} K_{\mathrm{w}, i} C_{\mathrm{w}}-\ln 2 T_{0.5, i}^{-1} C_{i}$,

where $C_{i}$ and $C_{\mathrm{f}, i}$ are the concentrations of radioactivity in the marine organisms and their food, respectively, $a_{i}$ is the assimilation efficiency, $b_{i}$ is the water extraction coefficient, $K_{\mathrm{f}, i}$ is the food uptake rate, $K_{\mathrm{w}, i}$ is the water uptake rate, and $T_{0.5, i}$ is the biological half-life of the radionuclide in the organism.

The activity concentration in the food of a predator $C_{\mathrm{f}, i}$ is expressed by the following equation, summing up for a total of $n$ prey types

$C_{\mathrm{f}, i}=\sum_{j=0}^{n} C_{\text {prey }, j} P_{i, j} \frac{\mathrm{drw}_{\text {pred }, i}}{\mathrm{drw}_{\text {prey }, j}}$,

where $C_{\text {prey, } j}$ is the activity concentration in prey of type $j$, $P_{i, j}$ is preference factor for prey of type $j, \mathrm{drw}_{\text {pred }, i}$ is the 
Table 1. Parameters of dynamic food chain model BURN.

\begin{tabular}{llllllll}
\hline$i$ & Organism & $\mathrm{drw}$ & $\begin{array}{l}K_{\mathrm{f}, i} \\
\mathrm{~d}^{-1}\end{array}$ & $a_{i}$ & $\begin{array}{l}K_{\mathrm{W}, i} \\
\mathrm{~m}^{3} \mathrm{~kg}^{-1} \mathrm{~d}^{-1}\end{array}$ & $b_{i}$ & $\begin{array}{l}T_{0.5, i} \\
\mathrm{~d}\end{array}$ \\
\hline 1 & Phytoplankton & 0.1 & & & & & \\
2 & Zooplankton & 0.1 & 1.0 & 0.2 & 1.5 & 0.001 & 5 \\
3 & Non-piscivorous fish & 0.25 & 0.03 & 0.5 & 0.1 & 0.001 & Table 3 \\
4 & Piscivorous fish & 0.3 & 0.007 & 0.7 & 0.075 & 0.001 & Table 3 \\
5 & Macroalgae & 0.1 & & & 0.6 & 0.001 & 60 \\
6 & Deposit-feeding & 0.1 & 0.02 & 0.3 & 0.1 & 0.001 & 15 \\
& invertebrate & & & & & 0.001 & 50 \\
7 & Mollusk & 0.1 & 0.06 & 0.5 & 0.15 & 0.001 & 100 \\
8 & Crustacean & 0.1 & 0.015 & 0.5 & 0.1 & 0.001 & Table 3 \\
9 & Demersal fish & 0.25 & 0.007 & 0.5 & 0.05 & 0.001 & Table 3 \\
10 & Bottom predator & 0.3 & 0.007 & 0.7 & 0.05 & 0.001 & Table 3 \\
11 & Coastal predator & 0.3 & 0.007 & 0.7 & 0.075 & & \\
\hline
\end{tabular}

dry weight fraction of predator of type of $i$, and $\operatorname{drw}_{\text {prey, }} j$ is the dry weight fraction of prey of type $j$. The index " 0 " corresponds to the bottom deposit in sediment (Fig. 1). The concentration of assimilated radioactivity from the organic fraction of sediment is related with the radioactivity concentration of the upper layer of bulk sediment as $C_{\text {prey, } 0}=\phi_{\text {org }} \cdot C_{\mathrm{s}}$. Here $\phi_{\text {org }}$ is an empirical parameter $\phi_{\text {org }}=$ $(1-p) f_{\mathrm{org}} C_{\mathrm{org}} C_{\mathrm{s}}^{-1}$, where $p$ is porosity, $f_{\text {org }}$ is the organic matter fraction, $C_{\mathrm{org}} C_{\mathrm{s}}^{-1}$ is the ratio of concentration $C_{\mathrm{org}}$ $\left(\mathrm{Bq} \mathrm{kg}^{-1}\right.$-dry) in the organic matter to the bulk sediment concentration $C_{\mathrm{s}}\left(\mathrm{Bq} \mathrm{kg}^{-1}\right.$-dry). The value of $\phi_{\text {org }}$ is in the range of 0.1-0.01 (Ono et al., 2015).

Values of the model parameters are given in Table 1. The parameters for pelagic and benthic food webs were compiled from published data (Baptist and Price, 1962; Cammen, 1980; Coughtrey and Thorne, 1983; Tateda, 1994, 1997; Vives i Batlle et al., 2007; Tateda et al., 2013; Iwata et al., 2013; Sohtome et al., 2014). The biological half-life data for fish flesh (Baptist and Price, 1962; Coughtrey and Thorne, 1983; Tateda, 1994, 1997; Zhao et al., 2001) show variability in a large range (35-180 days) due to the differences between species and due to the differences in the experiment methodology. In this generic model, values of $T_{0.5, i}$ were divided into two groups: $T_{0.5, i}=75 \mathrm{~d}$ for non-piscivorous fishes and demersal fishes feeding on invertebrates $(i=3$, 9 ), and $T_{0.5}=150 \mathrm{~d}$ for predatory fishes $(i=4,10,11)$. This is based on the assumptions that (a) larger fishes have longer $T_{0.5, i}$ due to the slower metabolic rates, and (b) predatory fishes are generally larger than prey fishes. The results of a sensitivity study to assess the robustness of these assumptions for $T_{0.5, i}$ are given in next section. An additional constraint on the values of the model parameters is the condition that, at equilibrium state, the BCF of the components of the food chain should be relevant to the values from IAEA (2004). The biological half-life for the bone was calculated for non-piscivorous and piscivorous fish using Eq. (3) and data for ${ }^{90} \mathrm{Sr}$ (known to accumulate mainly in bone tissue) using an equilibrium approximation to satisfy $\mathrm{BCF}$ values from IAEA (2004). The values of prey preference are given in Table 2. They are compiled from data on feeding habits of organisms (Fujita et al., 1995; Kasamatsu and Ishikawa, 1997; Iwata et al., 2013; Sohtome et al., 2014).

It is well established that the uptake of caesium decreases with increasing salinity due to the increase in concentration of competing potassium ions. This was taken into account when introducing the salinity-dependent correction factor $F_{K}$ for phytoplankton and macroalgae as caesium enters the food web primarily through the lowest trophic level whereas the contribution of direct uptake from water is minor (Heling and Bezhenar, 2009). The correction factor for $\mathrm{Cs}$, based on laboratory experiments with marine plants, was verified against field measurements in the Dnieper-Boog estuary (Heling and Bezhenar, 2011). It is expressed as

$$
F_{K}=\frac{0.05}{\exp \left(0.73 \ln \left(K^{+} / 39.1\right)-1.22 \times 10^{3} \Theta^{-1}\right)},
$$

where $K^{+}$is the potassium concentration $\left(\mathrm{mg} \mathrm{L}^{-1}\right)$ and $\Theta$ is temperature $(\mathrm{K})$. For water with a $K^{+}$concentration above $1.5 \mathrm{mg} \mathrm{L}^{-1}$, the potassium concentration could be linked to the salinity using the following relationship (Heling and Bezhenar, 2009):

$K^{+}=11.6 S-4.28$,

where $S$ is the salinity in $\mathrm{g} \mathrm{L}^{-1}$. The BCF for phytoplankton and macroalgae can be expressed by

$$
\mathrm{CF}_{\mathrm{ph}}=F_{K} \mathrm{CF}_{\mathrm{ph}}^{*}, \quad \mathrm{CF}_{\mathrm{ma}}=F_{K} \mathrm{CF}_{\mathrm{ma}}^{*} \text {, }
$$

where $\mathrm{CF}_{\mathrm{ph}}^{*}=20 \mathrm{~L} \mathrm{~kg}^{-1}$ and $\mathrm{CF}_{\text {ma }}^{*}=50 \mathrm{~L} \mathrm{~kg}^{-1}$ are standard $\mathrm{BCF}$ for marine environments (IAEA, 2004).

According to a review of radiological data (Coughtrey and Thorne, 1983; Yankovich et al., 2010), every radionuclide in fish accumulates mostly in a specific (target) tissue. Accord- 
Table 2. Preference factor of predator of type $i$ for prey of type $j$.

\begin{tabular}{llllllllll}
\hline $\begin{array}{l}\text { Predator } \\
\text { Prey }\end{array}$ & 2 & 3 & 4 & 6 & 7 & 8 & 9 & 10 & 11 \\
\hline 0 & & & & & & & & & \\
1 & 1.0 & & & 0.5 & & & 0.1 & & \\
2 & & 1.0 & & & 0.6 & 0.1 & & & \\
3 & & & 1.0 & & & & & & 0.8 \\
5 & & & & 0.5 & 0.2 & 0.1 & & & \\
6 & & & & & & & 0.7 & 0.3 & 0.25 \\
7 & & & & & & & 0.1 & 0.2 & 0.1 \\
8 & & & & & & & 0.1 & 0.2 & 0.2 \\
9 & & & & & & & & 0.3 & 0.25 \\
\hline
\end{tabular}

ing to data from Yankovich et al. (2010), amounts of radiocaesium in flesh, bone, and organs are 90,9 , and $1 \%$, respectively. Hence, Cs turnover in bones and organs is negligible. The target tissue (bone, flesh, organs, and stomach) is assumed to control the overall elimination rate of the nuclide $\left(T_{0.5, i}\right)$ in the organisms. The radioactivity in the food of a predator is therefore the activity concentration in the target tissue diluted by the remaining body mass of the prey, calculated by multiplying the predicted level in the target tissue by its weight fraction. For radiocaesium, the target tissue is flesh. To calculate the concentration in the edible part of fish from the calculated levels in the target tissues, a target tissue modifier (TTM) is introduced. This is based on tissue distribution information (Coughtrey and Thorne, 1983; Yankovich et al., 2010). Values of the described parameters for fish in a dynamic food chain model are given in Table 3.

The dynamic food chain model is part of the POSEIDONR (Lepicard et al., 2004; Maderich et al., 2014a, b) model where the marine environment is modelled as a system of compartments representing the water column, bottom sediment, and biota. The compartments describing the water column are subdivided into a number of vertical layers as shown in Fig. S1 in the Supplement. The model assumes partition of the radionuclides between the dissolved and particulate fractions in the water column, described by a distribution coefficient. The radionuclide concentration for each compartment is governed by a set of differential equations including the temporal variations of concentration, the exchange with adjacent compartments and with the suspended and bottom sediments, radioactive sources, and decay. The exchange between the water column boxes is described by fluxes of radionuclides due to advection, sediment settling, and turbulent diffusion processes. The activity loss in suspended sediments occurs through settling in underlying compartments and, finally, to the bottom. A three-layer model describes the transfer of radionuclides in the bottom sediments. The transfer of radioactivity from the upper sediment layer to the water column is described by diffusion in the interstitial water and by bioturbation. Radioactivity in the upper sediment layer migrates downwards by diffusion and by burial at a rate
Table 3. Parameters for fish in a dynamic food chain model.

\begin{tabular}{|c|c|c|c|c|}
\hline Target tissue & Bone & Flesh & Organs & Stomach \\
\hline Weight fraction & 0.12 & 0.80 & 0.05 & 0.03 \\
\hline Target tissue modifier & 0.5 & 1.0 & 0.5 & 0.5 \\
\hline $\begin{array}{l}\text { Biological half-life of } \\
\text { non-piscivorous fish (d) }\end{array}$ & 500 & 75 & 20 & 3 \\
\hline $\begin{array}{l}\text { Biological half-life of } \\
\text { piscivorous fish (d) }\end{array}$ & 1000 & 150 & 40 & 5 \\
\hline $\begin{array}{l}\text { Biological half-life of } \\
\text { demersal fish (d) }\end{array}$ & 500 & 75 & 20 & 3 \\
\hline $\begin{array}{l}\text { Biological half-life of } \\
\text { bottom predator fish (d) }\end{array}$ & 1000 & 150 & 40 & 5 \\
\hline $\begin{array}{l}\text { Biological half-life of } \\
\text { coastal predator fish (d) }\end{array}$ & 1000 & 150 & 40 & 5 \\
\hline
\end{tabular}

assumed to be the same at which particles settle from the overlying water. The upwards transfer of radioactivity from the mid-sediment layer to the top sediment layer occurs only by diffusion. Burial causes an effective loss of radioactivity from the middle to the deep sediment layer, from which no upward transfer occurs. The model equations are given in the Supplement. The model for the pelagic food web component was implemented for the whole area of study, whereas the benthic component was included in the shallow, singlewater-column layer compartments adjacent to the shore.

The POSEIDON-R model can handle different types of radioactive releases: atmospheric fallout, runoff from land deposited radionuclide by river systems, point sources associated with routine releases from nuclear facilities located either directly on the coast or inland at river systems, and point sources associated with accidental releases (Lepicard et al., 2004). For coastal discharges occurring in the large ("regional") boxes, "coastal" release boxes are nested into the regional box system. Advection and diffusion of zooplankton are not taken into account due to the short biological half-life (5 days) of Cs in these organisms, except in the coastal box, where diffusion exchange between coastal and regional compartments was considered. It was assumed that crustaceans, mollusks, and fish are not transported by ocean currents. When calculating the radionuclide concentration in fish in small coastal boxes, random fish migration is taken into account as in Maderich et al. (2014a, b). For this purpose, the right hand side of Eq. (3) for radionuclide concentration in fish, both in the inner $\left(C_{\mathrm{in}, i}\right)$ and outer $\left(C_{\text {out }, i}\right)$ compartments, is extended by the term $-\left(C_{\mathrm{in}, i}-C_{\mathrm{out}, i}\right) / T_{\mathrm{migr}, i}$ for the coastal compartment and by the term $\left(C_{\mathrm{in}, i}-C_{\mathrm{out}, i}\right) /\left(\delta T_{\mathrm{migr}, i}\right)$ for the outer compartment. Here $T_{\mathrm{migr}, i}$ is the characteristic time of fish migration from a coastal compartment, depending on compartment scale and fish species, and $\delta$ is the ratio between the volumes of the outer and the coastal compartments. 


\section{Application to the Fukushima Dai-ichi accident}

\subsection{Model setup}

The model was customized for the north-western Pacific Ocean, the East China and Yellow seas, and the Sea of Japan (East Sea). A total of 176 boxes cover this entire region (Fig. S2). In the deep-sea regions a three-layer box system was built to describe the vertical structure of the radioactivity transport in the upper layer $(0-200 \mathrm{~m})$, intermediate layer (200-1000 m), and deeper layer $(>1000 \mathrm{~m})$. The compartments around the FDNPP are shown in Fig. 2. The "coastal" box (placed at "F" in Fig. 2) covers $15 \times 30 \mathrm{~km}$ and is nested into a large "regional" box (box 90) in order to provide more detailed description in the area around the FDNPP. It covers a circular-shaped surface area of a radius $15 \mathrm{~km}$ centred at the FDNPP where observation data were collected. The coastal box has one vertical layer for the water column and three bottom sediment layers. It is shallower than the single-layer outer box 90 . The water exchanges with the outer box are equal in both directions. The averaged advective and diffusive fluxes between regional compartments were calculated for a 10-year period (2000-2009) using the Regional Ocean Modeling System (ROMS). The parameters of the coastal box are given in Table S1 in the Supplement. Details of customization are given by Maderich et al. (2014a, b). The values for parameters $\phi_{\mathrm{org}}=0.01$ and $T_{\mathrm{migr}, i}=0.7 \mathrm{yr}$ for $i=3$, $4,9,10,11$ were used.

The simulation of dispersion and fate of ${ }^{137} \mathrm{Cs}$ was carried for the period 1945-2010 to provide background concentrations of radiocaesium for the radiological assessment of the FDNPP accident for the period 2011-2020 and to verify the model with available data. The main source of ${ }^{137} \mathrm{Cs}$ in the north-western Pacific in the period 1945-2010 was from fallout due to atmospheric nuclear weapon tests. The fallout includes a global component, caused by the transport of radioactivity due to the general atmospheric circulation and subsequent deposition on the surface of the ocean and a regional component, caused by fallout from weapon tests carried out in the Marshall Islands, resulting in the contamination of the surface layer of the ocean. The annual deposition of ${ }^{137} \mathrm{Cs}$ for the period $1945-2005$, compiled from Nakano (2006) and Hirose et al. (2008), is shown in Fig. S3a. The concentrations of ${ }^{137} \mathrm{Cs}$ at the eastern and southern boundaries (Fig. S3b) of the computational domain (Fig. S2) were estimated by using both observations from the MARiS (Marine Information System) database (MARiS, 2015), and observations from Kang et al. (1997) and Nakano and Povinec (2003). These values represent both the effect from global deposition of ${ }^{137} \mathrm{Cs}$ on the north-eastern Pacific and the regional effect of weapon tests carried out in the Marshall Islands. For the prediction of the concentration of ${ }^{137} \mathrm{Cs}$ for the period 2005-2020, 5-year averaged deposition and the boundary concentrations during the period of 2000-2004 were extrapolated and corrected for radioactive decay. The

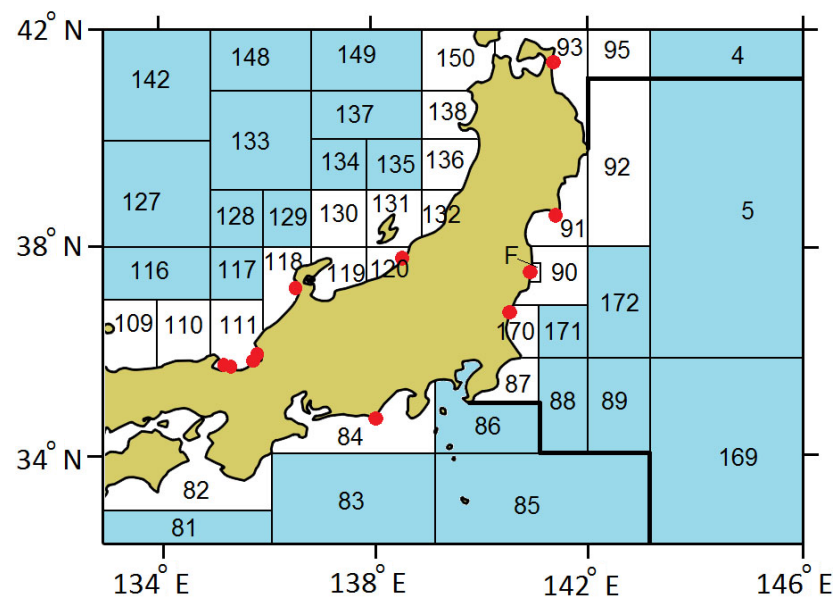

Figure 2. The box system for the area close to Fukushima Daiichi Nuclear Power Plant (FDNPP). The shaded boxes represent the deep-sea water boxes divided on three vertical layers. The NPPs are shown by filled circles. Coastal box around the FDNPP (marked by "F") is inside box 90 . A thick line delimits the area of the Fukushima accident fallout.

simulation for the period 1945-2010 was continued for the period of 2011-2020 with a source term estimated from the Fukushima accident. It was assumed that the release of activity directly to the ocean took place over the period 1-10 April 2011. Amounts of $5 \mathrm{PBq}$ of ${ }^{134} \mathrm{Cs}$, and $4 \mathrm{PBq}$ of ${ }^{137} \mathrm{Cs}$ were transferred directly into the coastal box. These quantities are in accordance with widely accepted source terms for the Fukushima accident simulations (see Povinec et al., 2013). The atmospheric deposition data were obtained from simulations with the MATCH model (Robertson et al., 1999) where the dispersion of ${ }^{137} \mathrm{Cs}$ for the period 12 March-5 April was computed (Maderich et al., 2014a). The ECMWF meteorological data with a source term reported by Stohl et al. (2012) were used in the simulation. The amount of deposited ${ }^{137} \mathrm{Cs}$ in the computational domain was $8.5 \mathrm{PBq}$. The deposition of ${ }^{134} \mathrm{Cs}$ was estimated at $10.2 \mathrm{PBq}$ using an activity ratio ${ }^{134} \mathrm{Cs} /{ }^{137} \mathrm{Cs}=1.2$. The atmospheric deposition was distributed between compartments as shown in Fig. 2. The continuous leakage into the coastal box from the middle of 2011 with a release rate of $3.6 \mathrm{TBq} \mathrm{yr}^{-1}$ (Kanda, 2013) was taken into account.

\subsection{Results}

The results from the modelling of the ${ }^{137} \mathrm{Cs}$ concentration in the water and in the upper layer of sediments of the coastal box are shown in Fig. 3. Model results for the water demonstrate good agreement both with yearly averaged observations by MEXT (the Japanese Ministry of Education, Culture, Sports, Science and Technology) for the period 1950-2010 (MEXT, 2010) and with observation by TEPCO (Tokyo Electric Power Company) for the period of 2011- 
2016 (TEPCO, 2016). Comparison of Fig. 3a with Fig. 9a from Maderich et al. (2014a) confirms that the model correctly simulated the almost constant concentration of ${ }^{137} \mathrm{Cs}$ in the water in the FDNPP vicinity due to the continued leak of radioactivity from FDNPP (Kanda, 2013). The geometric mean of the simulated-to-observed ratios is 1.03 with a geometric standard deviation (GSD) of 1.89 for a total number of observations $N=51$ in the period 1984-2016 when data are available.

The model also predicts well the concentration of ${ }^{137} \mathrm{Cs}$ in the bottom sediment before the accident and the sudden increase in concentration by more than 3 orders of magnitude as a result of the accident. However, after 2013 (Fig. 3b) the observed concentration decreases faster than the model prediction when a correction for vertical transfer is not included (see text below). The estimated decrease constant of the fitted exponential function of the measured sediment concentrations for 2012-2015 is $\lambda_{\mathrm{s}}=0.44 \mathrm{yr}^{-1}$. The concentrations of ${ }^{137} \mathrm{Cs}$ in the bottom sediment of the coastal areas (B, C, D) with a depths less than $50 \mathrm{~m}$ in the Fukushima Prefecture (Sohtome et al., 2014) show a similar decrease. The decrease constant for area B located north of FDNPP is $0.44 \mathrm{yr}^{-1}$ whereas for the smaller areas $\mathrm{C}$ and $\mathrm{D}$ located south of the FDNPP it is 0.63 and $0.7 \mathrm{yr}^{-1}$, respectively. For the deeper offshore area $\mathrm{F}$ adjacent to the areas $\mathrm{C}$ and $\mathrm{D}$ the value of the decrease is much slower $\left(0.24 \mathrm{yr}^{-1}\right)$. Several possible mechanisms could be responsible for the observed time-spatial redistribution of radioactivity in the surface layer of the sediments. According to Ambe et al. (2014) the vertical transfer of ${ }^{137} \mathrm{Cs}$ by resuspension and redeposition by ocean currents and waves, desorption to the pore water, and bioturbation can result in a decrease of ${ }^{137} \mathrm{Cs}$ concentration in the upper layer of sediments. Resuspension and lateral transport of the fine-grained sediments also can redistribute radiocaesium in the coastal sediments (Otosaka and Kobayashi, 2013). The simplified representation of the exchange processes in the upper layer of the sediment and the lack of re-suspension in the POSEIDON-R model cannot account for these processes. Therefore, to take into account the vertical transfer of ${ }^{137} \mathrm{Cs}$ we added the exchange terms $\left(C_{\mathrm{s}, 1}-C_{\mathrm{s}, 2}\right) \lambda_{\mathrm{s}}$ and $-\left(C_{\mathrm{s}, 1}-C_{\mathrm{s}, 2}\right) \lambda_{\mathrm{s}}$ to the right hand side of the Eqs. (S3) and (S4) for the concentration of radioactivity in the upper $\left(C_{\mathrm{s}, 1}\right)$ and medium $\left(C_{\mathrm{s}, 2}\right)$ layers of sediment in the coastal box, respectively. Here $\lambda_{\mathrm{s}}$ is an empirical parameter. The value of $\lambda_{\mathrm{s}}=0.4 \mathrm{yr}^{-1}$ was found to best fit observational data for $C_{\mathrm{s}, 1}$. As seen in Fig. $3 \mathrm{~b}$ the concentrations of ${ }^{137} \mathrm{Cs}$ are described well in period $2008-2015$ when an additional exchange term is incorporated into the model. The geometric mean of the simulated-to-observed ratios is 0.97 with GSD $=1.26(N=46)$ for the period 1984-2015.

The simulated ${ }^{137} \mathrm{Cs}$ concentrations in deposit-feeding invertebrates, demersal fishes, bottom predators, and coastal predators in the coastal box (placed at "F" in Fig. 2) are shown in Fig. 4 along with observed concentrations by the Japan Fisheries Research Agency (JFRA, 2015). The sym-
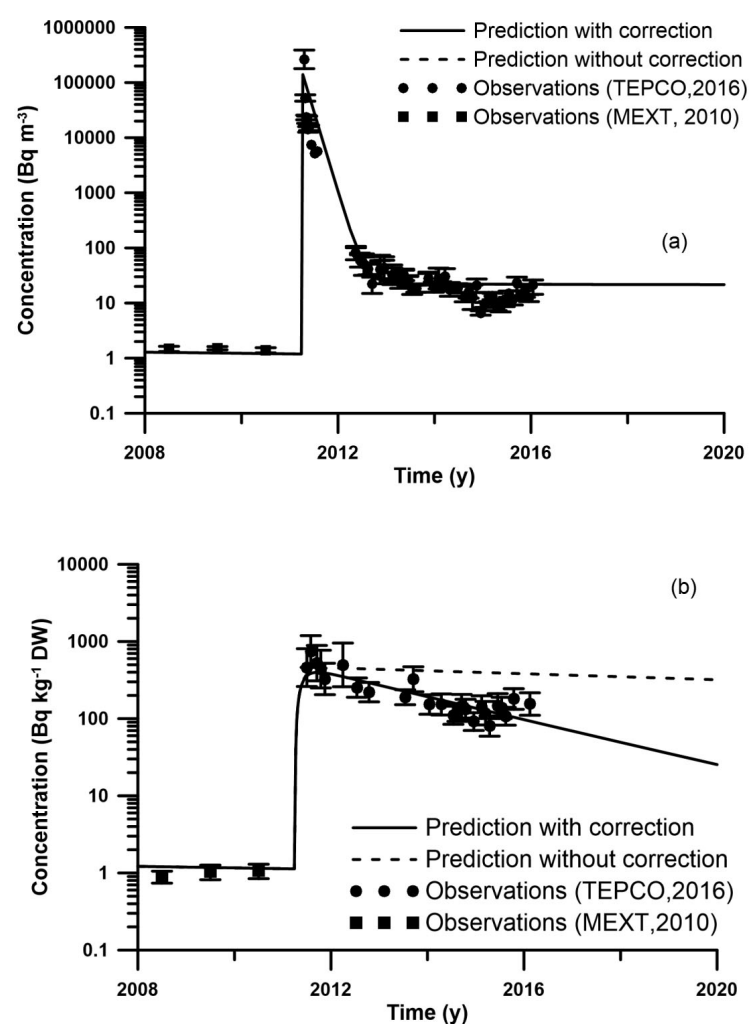

Figure 3. Comparison between calculated and observed ${ }^{137} \mathrm{Cs}$ concentration in seawater (a) and in bulk bottom sediment (b) in the coastal box around the FDNPP. Values in (b) are given in becquerels (Bq) per kilogram (kg) of dry weight (DW). The dashed line in (b) shows results of simulations using standard POSEIDON-R model, whereas the solid line presents simulation with the correction term in Eq. (S3).

bols in Fig. 4 are observation data for sea urchins (Strongylocentrotus nudus) (a), flounders (Microstomus achne, Kareius bicoloratus, Pleuronectes yokohamae) (b), and Japanese rockfish (Sebastes cheni) (c). The open and filled symbols in Fig. 4d are data for seabass (Lateolabrax japonicus) and fat greenling (Hexagrammos otakii), respectively. Just after the accident, the simulated ${ }^{137} \mathrm{Cs}$ concentration in the depositfeeding invertebrates and the observed concentration in the sea urchin increase due to the high concentration of ${ }^{137} \mathrm{Cs}$ in the water (Fig. 4a). After that, the concentration trend becomes similar to trends in the sediments (Fig. 3b). This is consistent with model diet that includes macroalgae and deposit organic matter grossly representing the diet of $S$. nudus (Lawrence, 2007). The macroalgae contribution to contamination from feeding first prevails. After 2012, the contamination from ingestion of bottom deposits dominates. The decrease constant of the fitted exponential function of simulated concentration (depuration constant) is $0.45 \mathrm{yr}^{-1}$, which is close to the decrease constant for the sediment observations $\left(0.44 \mathrm{yr}^{-1}\right)$. It agrees with observations by Sohtome et al. (2014) that concentration in sediment and in deposit- 

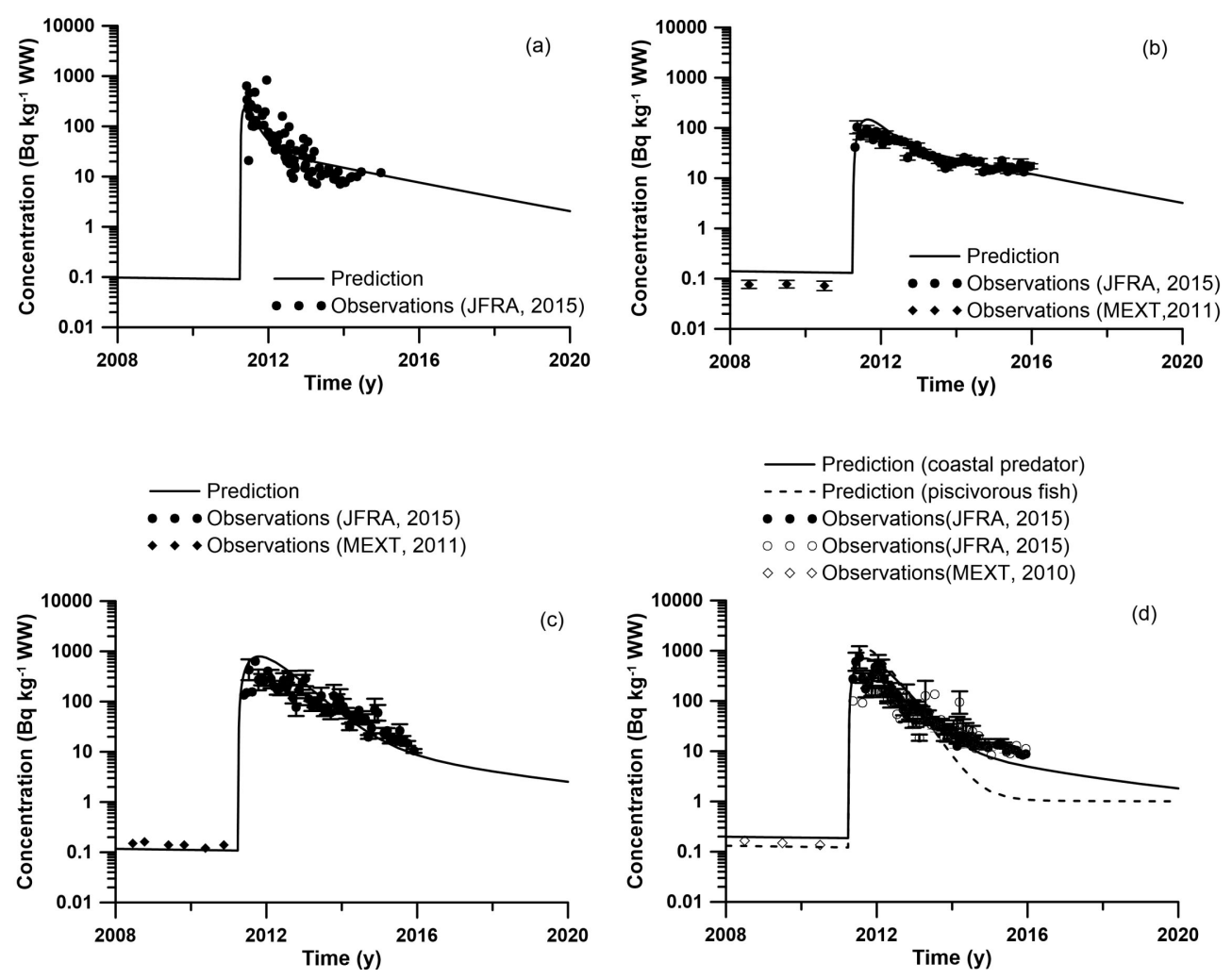

Figure 4. Comparison between calculated and observed ${ }^{137} \mathrm{Cs}$ concentration in deposit-feeding invertebrate (a), demersal fish (b), bottom predator (c), and coastal predator (d) around the FDNPP. Values are given in becquerels (Bq) per kilogram (kg) of wet weight (WW).

feeding benthic invertebrates show almost identical rates of decrease. The predicted transfer coefficient from bulk sediment to deposit-feeding benthic invertebrates for the period of 2012-2020 is approximately 0.07 . The field studies of several species of Polychaeta (deposit or filter feeders: Flabelligeridae, Terebellidae, and Opheliidae; herbivore or carnivore feeders: Glyceridae, Eunicidae, and Polynoidae) off the coast of Fukushima and rearing experiment for Perinereis aibuhitensis demonstrated that ${ }^{137} \mathrm{Cs}$ concentration in all specimens was much lower than that in the sediment (Shigenobu et al., 2015). Results of experiments using contaminated sediments from near the FDNPP showed that wet weight (WW)-based transfer coefficient (concentration ratio) between $P$. aibuhitensis and contaminated sediment was less than 0.1. The geometric mean of the simulated-to-observed ratios is 0.98 with $\mathrm{GSD}=1.41(N=21)$ for the period 20112015.

The results of simulation of the ${ }^{137} \mathrm{Cs}$ concentration in the demersal fishes (Fig. 4b) agree well with observations documented for several species of flounders. The geometric mean of the simulated-to-observed ratios is 1.16 with $\mathrm{GSD}=1.31$ $(N=49)$ for the period 1984-2015. The simulated value of the depuration constant is $0.46 \mathrm{yr}^{-1}$ whereas the value estimated from the field data for 2012-2015 (Fig. 4b) is $0.48 \mathrm{yr}^{-1}$. The gradual decrease of activity in demersal fish caused by the transfer of activity from organic matter deposited in the sediment is similar to observations by Wada et al. (2013). Notice that the predicted transfer coefficient from bulk sediment to demersal fish for the period of 20122020 is approximately 0.13 . This value is larger than that for deposit-feeding invertebrates. The observed BCF for demersal fish (flounders) in this area between 2013 and 2015 is $0.9 \mathrm{~m}^{3} \mathrm{~kg}^{-1}$, whereas the standard value of BCF for fish is $0.1 \mathrm{~m}^{3} \mathrm{~kg}^{-1}$ (IAEA, 2004). This confirms the importance of transfer of radiocaesium to demersal fish from the sediments. Comparison of simulations with observations for a bottom predator (Japanese rockfish) in Fig. 4c shows also good agreement. The geometric mean of the simulated-toobserved ratios is 0.84 with $\mathrm{GSD}=1.73(N=48)$ for the period 1984-2015. The comparison of simulated and observed concentrations of ${ }^{137} \mathrm{Cs}$ in coastal predators is given in Fig. 4d. The open and filled symbols are data for seabass and fat greenling, respectively. The geometric mean of the simulated-to-observed ratios is 1.16 with GSD $=1.89(N=$ 69) for the period 1984-2015. As seen in Fig. 4d, the simulated concentration of ${ }^{137} \mathrm{Cs}$ in coastal predators feeding on both pelagic and benthic organisms is similar to the simulated concentration in pelagic piscivorous fish during the period of 2011-2013. After 2013, the concentration in coastal predators decreases more slowly than in piscivorous fish due 


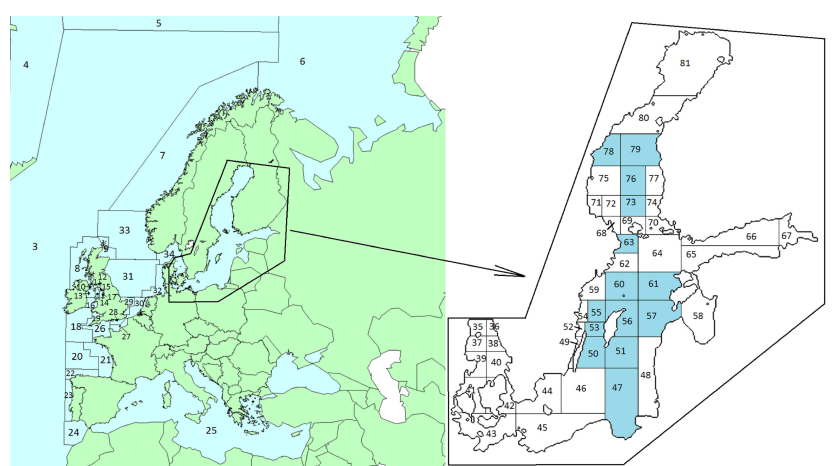

Figure 5. Compartment system of POSEIDON-R model for the north-eastern part of the Atlantic Ocean, the North Sea, and the Baltic Sea. The shaded boxes represent boxes with two vertical layers. All other boxes in the Baltic Sea consist of one vertical layer in the model.

to the omnivorous predation diet of coastal predators which includes benthic organisms.

The model output can be sensitive to the model parameters that have a high uncertainty. Therefore, a sensitivity study was carried out for the major benthic food web parameters including the water uptake rate $K_{\mathrm{w}, i}$, the food uptake rate $K_{\mathrm{f}, i}$, the biological half-life of ${ }^{137} \mathrm{Cs}$ in the organism $T_{0.5, i}$, and for the concentration ratio of assimilated radioactivity from the organic fraction in bottom sediment to the radioactivity in bulk bottom sediment $\phi_{\text {org }}$. The effects of variations in these parameters were estimated for the following model output: maximum ${ }^{137} \mathrm{Cs}$ concentration in the organisms $(i=2, \ldots$, 11) in the coastal box after the FDNPP accident. The range for $K_{\mathrm{w}, i}, K_{\mathrm{f}, i}, T_{0.5, i}$, and $\phi_{\text {org }}$ is defined following Keum et al. (2015) as follows: minimum value were set to half the reference value and maximum value were set to twice the reference value. The reference values for $K_{\mathrm{w}, i}, K_{\mathrm{f}, i}$, and $T_{0.5, i}$ are given in Tables 1 and 3, and $\phi_{\text {org }}=0.01$. The model output sensitivity was estimated using a sensitivity index (SI) calculated following Hamby (1994):

$\mathrm{SI}=\frac{D_{\max }-D_{\min }}{D_{\max }}$

where $D_{\max }$ and $D_{\min }$ are the simulation results for maximal and minimal parameter values, respectively.

Figure S4a shows that all organisms (except primary producers) are most sensitive to the variation of $K_{\mathrm{f}, i}$, however, sensitivity is higher for the pelagic components $(i=2,3)$ than for the benthic components $(i=7, \ldots, 11)$ of the food web, due to the higher diversity in the diet in bottom-feeding organisms. The effect of variations of the biological half-life for zooplankton $T_{0.5, i}$ is highest both for the pelagic and benthic food webs (Fig. S4b). The maximum ${ }^{137} \mathrm{Cs}$ concentration for zooplankton using the maximal value of $T_{0.5, i}$ increased by a factor 2.7 compared to the concentration when the minimum value of $T_{0.5, i}$ was used. For pelagic fish and coastal predators this factor ranged between 1.7 and 2.4, whereas for the rest of the organisms it was smaller. The biological half-life $T_{0.5,6}$ of deposit-feeding invertebrates essentially influences ${ }^{137} \mathrm{Cs}$ concentration in demersal fish $(i=9)$. Figure S4c shows that the effect of variations in the water uptake rate for zooplankton $K_{\mathrm{w}, 2}$ decreased in organisms at higher trophic levels, showing good agreement with results by Keum et al. (2015). The concentrations of ${ }^{137} \mathrm{Cs}$ in macroalgae and deposit-feeding invertebrates are found to be 3 times more sensitive to the variations in water uptake rates than other food web compartments. The benthic organisms were less sensitive to the changes in $\phi_{\text {org }}$ (Fig. S4d).

\section{Modelling the effects from the Chernobyl accident on marine organisms in the Baltic Sea}

\subsection{Model setup}

The Baltic Sea is an important case because of transfer of ${ }^{137} \mathrm{Cs}$ originating from the Chernobyl fallout through its water-sediment-biota system. It was chosen to verify the ability of the model with generic parameters to describe transfer processes in a semi-enclosed sea with very different oceanography than the west coast of Japan. The model was customized for the Baltic Sea, the North Sea, and the North Atlantic Ocean with a total of 81 regional boxes (Fig. 5). The volume and average depth for the 47 boxes describing the Baltic Sea are derived from bathymetric data. A water column with a depth of more than $60 \mathrm{~m}$ is divided into two layers (surface and bottom) to allow for activity stratification in the water column. These boxes are marked blue in Fig. 5. The exchange of water between the boxes in the Baltic Sea is based on a 10-year average (1991-2000) of three-dimensional currents from a reanalysis based on the Swedish Meteorological and Hydrological Institute (SMHI) model (SMHI, 2013, unpublished data). The exchange rates for the remainder of the boxes were adopted from the standard POSEIDON configuration (Lepicard et al., 2004). To consider the water balance of the Baltic Sea and the inflow of radioactivity from river runoff, an additional 16 boxes were defined to represent main rivers in the basin (Table S2). The inflow of river water for each box is based on information reported by Leppäranta and Myrberg (2009). The total inflow of water into the rivers is $484 \mathrm{~km}^{3} \mathrm{yr}^{-1}$. Concentrations of suspended sediments (different for each box) was calculated by a 3-D hydrodynamic THREETOX model (Margvelashvily et al., 1997; Maderich et al., 2008). The bottom sediment classes for simulation were determined using data from Winterhalter et al. (1981). The simulation of transport and fate of ${ }^{137} \mathrm{Cs}$ in the Baltic Sea was carried out for the period 1945-2020. The main sources of ${ }^{137} \mathrm{Cs}$ as included in this model are global deposition from weapon testing and from the Chernobyl accident (HELCOM, 1995), release from the Sellafield and La Hague reprocessing plants (HELCOM, 2009), regional deposition from the Chernobyl accident in May 1986 (HELCOM, 1995), and river 

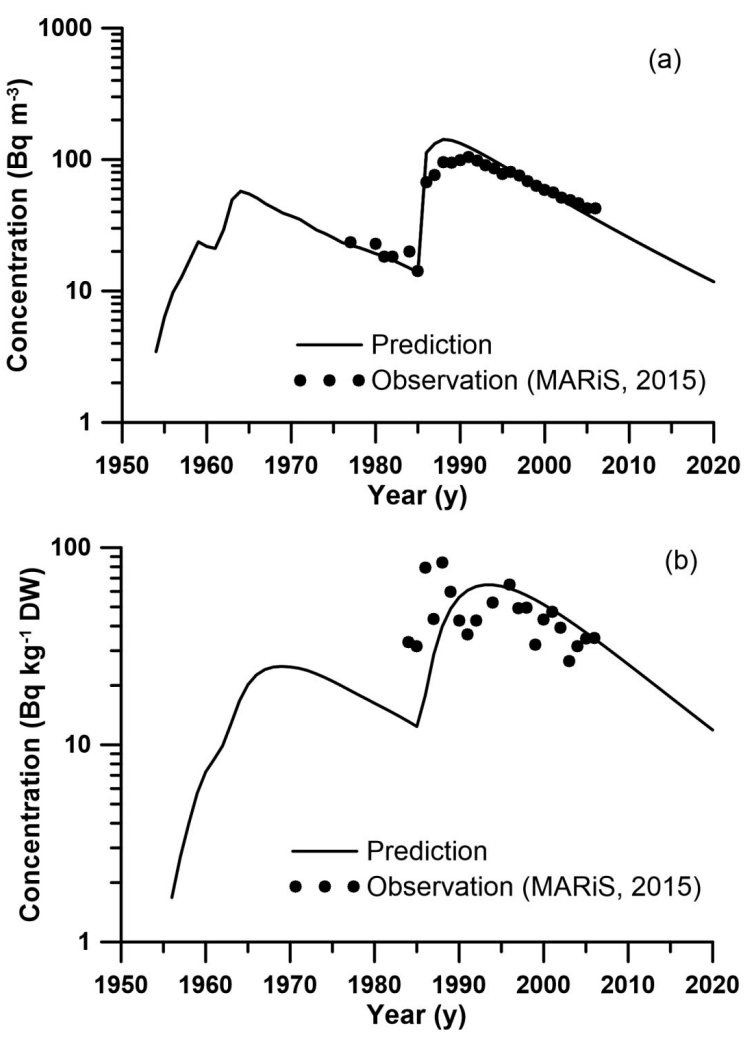

Figure 6. Comparison between calculated and observed ${ }^{137} \mathrm{Cs}$ concentrations in seawater (a) and in bulk bottom sediment (b) for box number 45 . Values in (b) are given in becquerels (Bq) per kilogram (kg) of dry weight (DW).

runoff. Details of these main sources are shown in Fig. S5a (global deposition), and in Fig. S5b (Sellafield and La Hague releases), as well as in Table S3 (Chernobyl accident). The river runoff from corresponding catchment areas was calculated using a generic model by Smith et al. (2004). The value for $\phi_{\text {org }}$ was set to 0.02 .

\subsection{Results}

The simulation results for the period of 1945-2020 are shown in Figs. 6-7 for box 45 where data on concentrations in the water, the sediment, and the biota are most detailed (MARiS, 2015; MORS, 2015). Time variations of ${ }^{137} \mathrm{Cs}$ concentration in the water and sediments in Fig. 6 show two maxima related with weapon testing and the Chernobyl accident and then followed by a decrease due to outflow to the North Sea and radioactive decay. The decrease constants of the fitted exponential function of the simulated concentrations in the water $\left(0.081 \mathrm{yr}^{-1}\right)$ and sediments $\left(0.070 \mathrm{yr}^{-} 1\right)$ are similar unlike the Fukushima accident where the plume of contaminated water quickly dissolves in the open ocean. The simulation results are in good agreement with the measurements. The geometric mean of the simulated-to-observed ratios for concentration in the water and sediment for the whole Baltic Sea are
0.89 with $\mathrm{GSD}=1.42(N=378)$ and 0.86 with $\mathrm{GSD}=2.17$ $(N=163)$, respectively.

Figure 7 shows a comparison between the calculated and observed ${ }^{137} \mathrm{Cs}$ concentration in marine organisms for box 45. The symbols in Fig. 7 are observation data for echinoderms (Echinodermata) (a), sprat (Sprattus sprattus) (b), European flounder (Platichthys flesus) (c), and Atlantic cod (Gadus morhua) (d). Comparison of the calculated concentrations of ${ }^{137} \mathrm{Cs}$ in the deposit-feeding invertebrates with the measurements (Fig. 7a) shows that the model correctly predicts the time-varying concentration in these organisms. The assessment of the model accuracy in this case is, however, hardly possible because of the small number of measurements. Calculated and observed concentrations of ${ }^{137} \mathrm{Cs}$ in pelagic non-piscivorous fish (sprat) demonstrate a good agreement with the measurements (Fig. 7b). The geometric mean for the simulated-to-observed ratios is 0.91 with $\mathrm{GSD}=1.32(N=24)$ for the whole Baltic Sea. Using the standard model with a constant value of $\mathrm{CF}_{\mathrm{ph}}$ (IAEA, 2004) for brackish waters leads to a significant underestimation of the concentration in fish: the geometric mean for the simulated-to-observed ratio is 0.68 with $\mathrm{GSD}=1.33$. Comparison of calculated and observed concentrations of ${ }^{137} \mathrm{Cs}$ in demersal fish (European flounder) showed slower decrease compared to the non-piscivorous fish (Fig. 7b) due to the difference in the food source between these species (Fig. 1). This benthic food web depends on the ${ }^{137} \mathrm{Cs}$ concentration in sediments (Fig. 6b), which follows the ${ }^{137} \mathrm{Cs}$ concentration in water with some delay (Fig. 6a). The geometric mean for the simulated-to-observed ratios is 0.92 with GSD $=1.67(N=70)$ for the whole Baltic Sea. Calculated ${ }^{137} \mathrm{Cs}$ concentration in the coastal predator (cod) also agree well with the measurements (Fig. 7d). The diet of Atlantic cod in the shallow western Baltic is diverse, including herring, sprat, Gobiidae, mollusks, various Polychaeta, and crustaceans (Sparholt, 1994). Therefore for this basin cod is considered as "coastal predator" feeding on both pelagic and benthic preys. The geometric mean for the simulatedto-observed ratios is 0.91 with $\mathrm{GSD}=1.37(N=95)$ for the whole Baltic Sea. The concentrations of ${ }^{137} \mathrm{Cs}$ in the coastal predators are larger than in piscivorous fish due to the benthic food web included in the model (Fig. 7d).

In contrast to the open Pacific Ocean coast where the FDNPP is located, concentrations in demersal fish, pelagic, and coastal predators after the Chernobyl accident decrease at almost similar rates (about $0.075 \mathrm{yr}^{-1}$ ). The variation in decrease rate is approximately $10 \%$ with a values of $0.081 \mathrm{yr}^{-1}$ for water and $0.07 \mathrm{yr}^{-1}$ for sediments. The observed BCFs in this area for sprat, European flounder, and Atlantic cod in 1990-2010 are $0.11,0.14$, and $0.15 \mathrm{~m}^{3} \mathrm{~kg}^{-1}$, respectively. This is close to the standard value of $\mathrm{BCF}$ for fish $0.1 \mathrm{~m}^{3} \mathrm{~kg}^{-1}$ (IAEA, 2004) after accounting for the fact that the Baltic Sea is brackish which affects the uptake rate of radiocaesium. These results essentially differ from the Fukushima case where BCF for demersal fish was an order of 

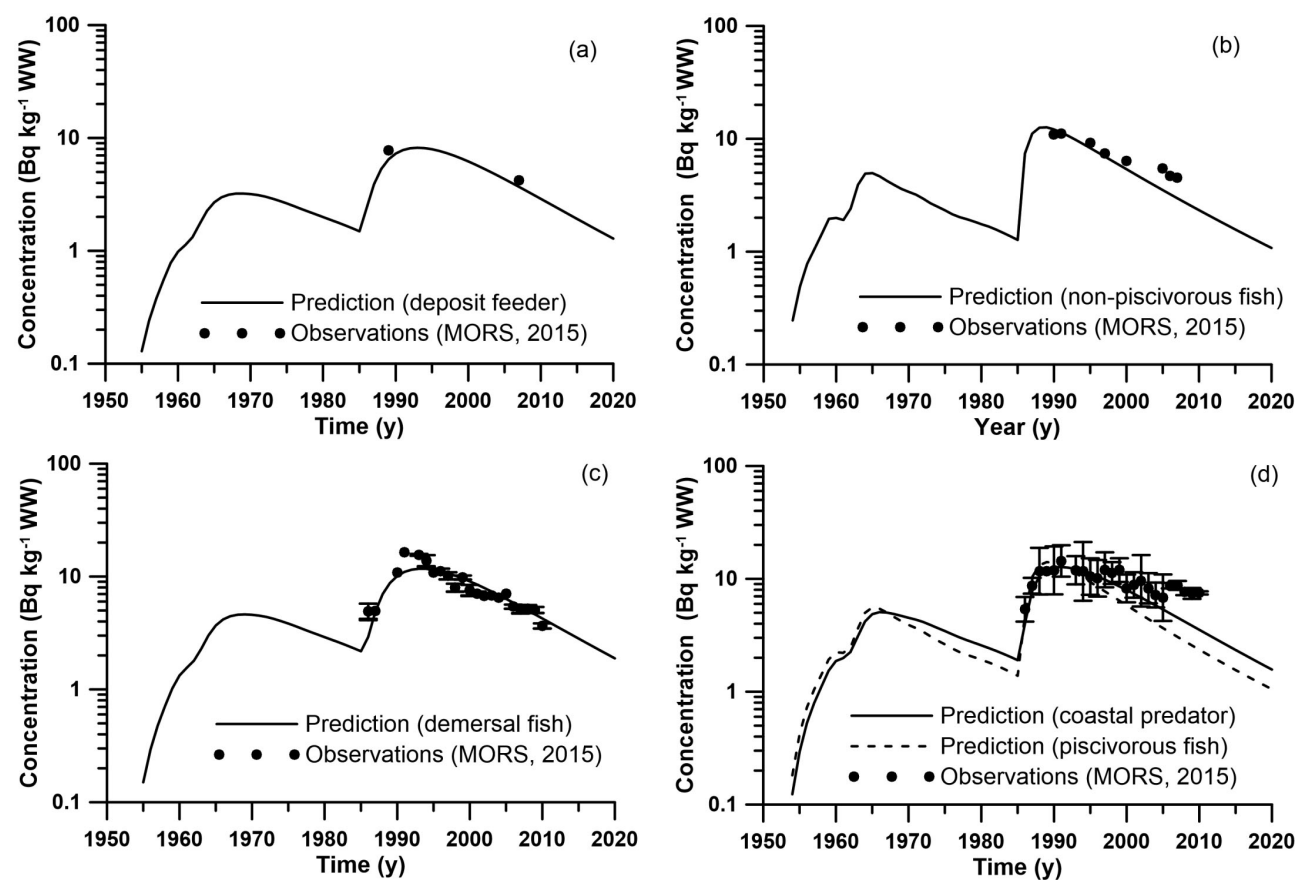

Figure 7. Comparison between calculated and observed ${ }^{137} \mathrm{Cs}$ concentrations in deposit-feeding invertebrate (a), non-piscivorous fish (b), demersal fish (c), and coastal predator (d) for box number 45. Values are given in becquerels (Bq) per kilogram (kg) of wet weight (WW).

magnitude larger confirming the importance of transfer from the sediments to demersal fish in the later case. The weak water exchange with the North Sea in the semi-enclosed Baltic Sea results in a slow decrease of concentration of watersediment-biota system reaching a quasi-equilibrium state. Notice that the food web model parameters, except for the correction for brackish waters, are the same as for the FDNPP case study demonstrating the generic character of the model.

\section{Conclusions}

A generic dynamic food web model was extended to include the benthic component of the marine food web. In the model, pelagic organisms were grouped into phytoplankton, zooplankton, non-piscivorous fish, and piscivorous fish (Heling et al., 2002). Benthic organisms were grouped into deposit-feeding invertebrate, demersal fish, and bottom predators. The food web also includes crustaceans, mollusks, and coastal predators. The model takes into account the salinity effect on the intake of radiocaesium. The food web model is embedded into the POSEIDON-R compartment model (Lepicard et al., 2004; Maderich et al., 2014a, b) where the marine environment comprises the water column, bottom sediment, and biota. The compartment model was applied to two regions (north-western Pacific (NWP) and the Baltic Sea) which were contaminated due to accidents on the Fukushima Dai-ichi and Chernobyl NPPs, respectively. Re- sults of simulations were compared with available data for the period of 1945-2015. Model results confirmed the presence of a continuous leakage of ${ }^{137} \mathrm{Cs}$ from Fukushima Daiichi NPP at a rate of $3.6 \mathrm{TBq} \mathrm{yr}^{-1}$ resulting in an almost constant concentration of ${ }^{137} \mathrm{Cs}$ in an area of $15 \times 30 \mathrm{~km}$ around the NPP. The ${ }^{137} \mathrm{Cs}$ decrease in the upper layer of the sediments in this area was faster than POSEIDON-R predictions using the standard marine compartment model parameterization where exchange between water and sediments occurs through diffusion. A simple parameterization constrained by measurements was therefore used to correct exchange rates. These results indicate that the further studies of exchange mechanisms are necessary. The decrease rate for the simulated ${ }^{137} \mathrm{Cs}$ concentrations in deposit-feeding invertebrates $\left(0.45 \mathrm{yr}^{-1}\right)$ is similar to the rate for sediments $\left(0.44 \mathrm{yr}^{-1}\right)$ found experimentally. This is the result of a diverse diet in invertebrates, in agreement with the results from Sohtome et al. (2014). The model-predicted low (0.07) transfer coefficient of radiocaesium from bulk sediment to depositfeeding benthic invertebrates in the area around the FDNPP for the period of 2012-2020 is consistent with observations and rearing experiments (Shigenobu et al., 2015). The findings are comparable with observations by Wada et al. (2013) showing a gradual decrease of activity in the demersal fish (decrease constant is $0.46 \mathrm{yr}^{-1}$ ) caused by transfer of activity from organic matter deposited in sediments through depositfeeding invertebrates. The estimated model transfer coefficient from bulk sediments to demersal fish for the period of 2012-2020 (0.13) is larger than that for deposit-feeding 
invertebrates. This value can be used to map demersal fish contamination from bottom sediments. The concentration in coastal predators that feed on both pelagic and benthic organisms is similar to the concentration in pelagic piscivorous fish for the period of 2011-2013 when the effects of direct contamination from the surrounding waters were dominant. After 2013, the concentration in coastal predators decreased more slowly than in piscivorous fish due to the omnivorous predation diet of coastal predators that includes benthic organisms.

The results of the application of POSEIDON-R with an extended dynamic model to the Baltic Sea which is semienclosed and brackish are in good agreement with available measurements. Unlike the highly dynamical off-coast processes caused by eddy-dominated currents in the $\mathrm{Pa}$ cific Ocean where the FDNPP is located, weak water exchange with the North Sea results in a slow quasi-equilibrium state of the water-sediment-biota system in the Baltic Sea. The Chernobyl case confirms that the standard parameterization of water-sediment exchange used in POSEIDON$\mathrm{R}$ describes well the exchange processes for the Baltic Sea whereas in the Fukushima study the observed value of ${ }^{137} \mathrm{Cs}$ decreased faster in the upper layer of the sediments than predictions from the standard model. In the Fukushima case, concentrations of ${ }^{137} \mathrm{Cs}$ in piscivorous fish decreased faster than in coastal predators whereas in the Chernobyl case, concentrations in both types of organisms behaved similarly. In general, our results demonstrate the importance of the benthic food chain in the long-term transfer of ${ }^{137} \mathrm{Cs}$ to marine organisms and the potential use of a generic model in different regions of the world's oceans.

\section{Data availability}

Global data on concentration of radionuclides in water, sediments and biota are accessible from Marine Information System (MARiS) at: http://maris.iaea.org/. Monitoring data around the FDNPP before 2015 are accessible at the Tokyo Electric Power Company (TEPCO), http://www.tepco.co. jp/en/nu/fukushima-np/index-e.html. From 2015 these data are accessible from http://radioactivity.nsr.go.jp/en/list/246/ list-1.html. Results of the inspection on radioactivity materials in fisheries' products are accessible at Japan Fisheries Research Agency (JFRA), http://www.jfa.maff.go.jp/ e/inspection/index.html. Monitoring data on the radioactivity in water, sediments and biota around the Japan coast are accessible from Japanese Ministry of Education, Culture, Sports, Science and Technology (MEXT) database at http://search.kankyo-hoshano.go.jp/servlet/search. Monitoring data on the radioactivity in water, sediments and biota in the Baltic Sea are accessible from Monitoring of Radioactive Substances (MORS) database http://www.helcom. fi/Pages/MORS-Discharge-database.aspx.

\author{
The Supplement related to this article is available online \\ at doi:10.5194/bg-13-3021-2016-supplement.
}

Acknowledgements. This work was supported by FP7-Fission2012 project PREPARE “Innovative integrative tools and platforms to be prepared for radiological emergencies and post-accident response in Europe", KIOST major project (PE99304), CKJORC (China-Korea Joint Ocean Research Center) Project for Nuclear Safety and State Fund for Fundamental Research of Ukraine project $\Phi 68 / 12879$ "Transfer of radioactivity between contaminated bottom sediment and the marine environment after Fukushima and Chernobyl accidents". We wish to acknowledge the anonymous reviewers whose valuable comments and suggestions have helped to improve the final manuscript and the handling editor Christine Klaas.

Edited by: C. Klaas

\section{References}

Ambe, D., Kaeriyama, H., Shigenobu, Y., Fujimoto, K., Ono, T., Sawada, H., Saito, H., Miki, S., Setou, T., Morita, T., and Watanabe, T.: A high-resolved spatial distribution of radiocesium in sea sediment derived from Fukushima Dai-ichi Nuclear Power Plant, J. Environ. Radioactivity, 133, 264-275, 2014.

Baptist, J. P. and Price, T. J.: Accumulation and retention of Cesium 137 by marine fishes, Fishery Bull., 206, 177-187, 1962.

Black, E. E. and Buesseler, K. O.: Spatial variability and the fate of cesium in coastal sediments near Fukushima, Japan, Biogeosciences, 11, 5123-5137, doi:10.5194/bg-11-5123-2014, 2014.

Buesseler, K. O., Jayne, S. R., Fisher, N. S., Rypina, I. I., Baumann, H., Baumann, Z., Breier, C. F., Douglass, E. M., George, J., Macdonald, A. M., Miyamoto, H., Nishikawa, J., Pike, S. M., and Yoshida, S.: Fukushima-derived radionuclides in the ocean and biota off Japan, P. Natl. Acad. Sci. USA, 109, 5984-5988, 2012.

Cammen, L. M.: Ingestion rate: An empirical model for aquatic deposit feeders and detritivores, Oecologia, 44, 303-310, 1980.

Coughtrey, P. J. and Thorne, M. C. Radionuclide distribution and transport in terrestrial and aquatic ecosystems: A critical review of data, vol 2, A. A. Balkema, Rotterdam, 1983.

Fowler, S. W., Buat-Menard, P., Yokoyama, Y., Ballestra, S., Holm, E., and Nguyen, H. V. Rapid removal of Chernobyl fallout from Mediterranean surface waters by biological activity, Nature, 329, 56-58, 1987.

Fujita, T., Kitagawa, D., Okuyama, Y., Ishito, Y., Inada, T., and Jin, Y. Diets of the demersal fishes on the shelf off Iwate, northern Japan, Mar. Biol., 123, 219-233, 1995.

Hamby, D. M.: A review of techniques for parameter sensitivity analysis of environmental models, Environ. Monit. Assess., 32, 135-154, 1994.

HELCOM (Helsinki Convention on the Protection of the Marine Environment of the Baltic Sea Area): Radioactivity in the Baltic Sea 1984-1991, Balt. Sea Environ. Proc., No. 61, 182 pp., 1995.

HELCOM: Radioactivity in the Baltic Sea 1999-2006, Balt. Sea Environ. Proc. No. 117, 64 pp., 2009. 
Heling, R. and Bezhenar, R.: Modification of the dynamic radionuclide uptake model BURN by salinity driven transfer parameters for the marine foodweb and its integration in POSEIDON-R, Radioprotection, 44, 741-746, 2009.

Heling, R. and Bezhenar, R.: The validation of the dynamic food chain model BURN-POSEIDON on Cs-137 and Sr-90 data of the Dnieper-Bug Estuary, Ukraine, Radioprotection, 46, 561-566, 2011

Heling, R., Koziy, L., and Bulgakov, V.: On the dynamical uptake model developed for the uptake of radionuclides in marine organisms for the POSEIDON-R model system, Radioprotection, 37, 833-838, 2002.

Hirose, K., Igarashi, Y., and Aoyama, M.: Analysis of the 50-year records of the atmospheric deposition of long-lived radionuclides in Japan, Applied Radiation and Isotopes, 66, 1675-1678, 2008.

IAEA (International Atomic Energy Agency): Sediment distribution coefficients and concentration factors for biota in the marine environment, Technical Report Series No 422, IAEA, Vienna, Austria, 2004.

Iwata, K., Tagami, K., and Uchida, S.: Ecological half-lives of radiocesium in 16 species in marine biota after the TEPCO Fukushima Daiichi Nuclear Power Plant accident, Environ. Sci. Technol., 47, 7696-7703, 2013.

JFRA (Japan Fisheries Research Agency): Results of the inspection on radioactivity materials in fisheries products, available at http: //www.jfa.maff.go.jp/e/inspection/index.html, 2015.

Kanda, J.: Continuing ${ }^{137}$ Cs release to the sea from the Fukushima Dai-ichi Nuclear Power Plant through 2012, Biogeosciences, 10, 6107-6113, doi:10.5194/bg-10-6107-2013, 2013.

Kang, D.-J., Chung, C.S., Kim, S. H., Kim, K.-R., and Hong, G. H.: Distribution of ${ }^{137} \mathrm{Cs}$ and ${ }^{239,240} \mathrm{Pu}$ in the surface waters of the East Sea (Sea of Japan), Mar. Pollut. Bull., 35, 305-312, 1997.

Kasamatsu, F. and Ishikawa, Y.: Natural variation of radionuclide ${ }^{137} \mathrm{Cs}$ concentration in marine organisms with special reference to the effect of food habits and trophic level, Mar. Ecol. Prog. Ser., 160, 109-120, 1997.

Keum, D.-K., Jun, I., Kim, B.-H., Lim, K.-M., and Choi, Y.-H.: A dynamic model to estimate the activity concentration and whole body dose rate of marine biota as consequences of a nuclear accident, J. Environ. Radioactivity, 140, 84-94, 2015.

Kim, Y., Cho, S., Kang, H. D., Kim, W., Lee, H. R., Doh, S. H., Kim, K., Yun, S. G., Kim, D. S., and Jeong, G. Y.: Radiocesium reaction with illite and organic matter in marine sediment, Mar. Pollut. Bull., 52, 659-665, 2006.

Koyanagi, T., Nakahara, M., and Iimura, M.: Absorption of sediment-bound radionuclides through the digestive tract of marine demersal fishes, J. Radiat. Res., 19, 295-305, 1978.

Kusakabe, M., Oikawa, S., Takata, H., and Misonoo, J.: Spatiotemporal distributions of Fukushima-derived radionuclides in nearby marine surface sediments, Biogeosciences, 10, 50195030, doi:10.5194/bg-10-5019-2013, 2013.

Lawrence, J. M. (Ed.): Edible sea urchins: Biology and ecology. Developments in Aquaculture and Fisheries Science, 37, Elsevier, Amsterdam, the Netherlands, 529 pp., 2007.

Lepicard, S., Heling, R., and Maderich, V.: POSEIDON-R/RODOS models for radiological assessment of marine environment after accidental releases: application to coastal areas of the Baltic, Black and North Seas, J. Environ. Radioactivity, 72, 153-161, 2004.
Leppäranta, M. and Myrberg, R.: Physical Oceanography of the Baltic Sea, Praxis Publishing Ltd, Chichester, UK, 2009.

Maderich, V., Heling, R., Bezhenar, R., Brovchenko, I., Jenner, H., Koshebutskyy, V., Kuschan, A., and Terletska, K. Development and application of 3D numerical model THREETOX to the prediction of cooling water transport and mixing in the inland and coastal waters, Hydrol. Process., 22, 1000-1013, 2008.

Maderich, V., Bezhenar, R., Heling, R., de With, G., Jung, K. T., Myoung, J. G., Cho, Y.-K., Qiao, F., and Robertson, L.: Regional long-term model of radioactivity dispersion and fate in the Northwestern Pacific and adjacent seas: application to the Fukushima Dai-ichi accident, J. Environ. Radioactivity, 131, 4-18, 2014a.

Maderich, V., Jung, K. T., Bezhenar, R., de With, G., Qiao, F., Casacuberta, N., Masque, P., and Kim, Y. H.: Dispersion and fate of ${ }^{90} \mathrm{Sr}$ in the Northwestern Pacific and adjacent seas: global fallout and the Fukushima Dai-ichi accident, Sci. Total Environ., 494-495, 261-271, 2014b.

Margvelashvily, N., Maderich, V., and Zheleznyak, M. THREETOX - computer code to simulate three-dimensional dispersion of radionuclides in homogeneous and stratified water bodies, Radiat Prot. Dosim., 73, 177-180, 1997.

MARiS (Marine Information System): Radioactivity and stable isotope data in the marine environment, available at: http://maris iaea.org/ (last access: May 2016), 2015.

MEXT (Japanese Ministry of Education, Culture, Sports, Science and Technology) Environmental radiation database, available at: http://search.kankyo-hoshano.go.jp/servlet/search.top (last access: May 2016), 2013.

MORS (Monitoring of Radioactive Substances). HELCOM MORS database, available at: http://www.helcom.fi/Pages/ MORS-Discharge-database.aspx (last access: May 2016), 2015.

Nakano, M.: Simulation of the advection-diffusion-scavenging processes for ${ }^{137} \mathrm{Cs}$ and ${ }^{239,240} \mathrm{Pu}$ in the Japan Sea, Radioactiv. Environm., 8, 433-448, 2006.

Nakano, M. and Povinec, P. P.: Oceanic general circulation model for the assessment of the distribution of ${ }^{137} \mathrm{Cs}$ in the world ocean, Deep-sea Res. II, 50, 2803-2816, 2003.

Nakano, M. and Povinec, P. P.: Long-term simulations of the ${ }^{137} \mathrm{Cs}$ dispersion from the Fukushima accident in the world ocean, J. Environ. Radioactivity, 111, 109-115, 2012.

Ono, T., Ambe, D., Kaeriyama, H., Shigenobu, Y., Fujimoto, K., Sogame, K., Nishiura, N., Fujikawa, T., Morita, T., and Watanabe, T.: Concentration of ${ }^{134} \mathrm{Cs}+{ }^{137} \mathrm{Cs}$ bonded to the organic fraction of sediments offshore Fukushima, Japan. Geochem. J., 49, 219-227, 2015.

Otosaka, S. and Kobayashi, T.: Sedimentation and remobilization of radiocesium in the coastal area of Ibaraki, $70 \mathrm{~km}$ south of the Fukushima Dai-ichi Nuclear Power Plant, Environ. Monit. Assess., 185, 5419-5433, 2013.

Periañez, R., Bezhenar, R., Iosjpe, M., Maderich, V., Nies, H., Osvath, I., Outola, I., and de With, G.: A comparison of marine radionuclide dispersion models for the Baltic Sea in the frame of IAEA MODARIA program, J. Environ. Radioactivity, 139, 6677, 2015.

Povinec, P., Hirose, K., and Aoyama, M.: Fukushima accident: Radioactivity impact on the environment, Elsevier, 2013.

Robertson, L., Langner, J., and Engardt, M.: An Eulerian limitedarea atmospheric transport model, J. Appl. Meteor., 38, 190-210, 1999. 
Shigenobu, Y., Ambe, D., Kaeriyama, H., Sohtome, T., Mizuno, T., Koshiishi, Y., Yamasaki, S., and Ono T.: Investigation of radiocesium translation from contaminated sediment to benthic organisms, in: Impacts of the Fukushima Nuclear Accident on Fish and Fishing Grounds, Chapter 7, edited by: Nakata, K. and Sugisaka, H., Springer, Tokyo, 91-98, 2015.

Smith, J. T., Wright, S. M., Cross, M. A., Monte, L., Kudelsky, A. V., Saxen, R., Vakulovsky, S. M., and Timms, D. N.: Global analysis of the riverine transport of ${ }^{90} \mathrm{Sr}$ and ${ }^{137} \mathrm{Cs}$, Environ. Sci. Technol., 38, 850-857, 2004.

Sohtome, T., Wada, T., Mizuno, T, Nemoto, Y., Igarashi, S., Nishimune, A., Aono, T., Ito, Y., Kanda, J., and Ishimaru, T.: Radiological impact of TEPCO's Fukushima Dai-ichi Nuclear Power Plant accident on invertebrates in the coastal benthic food web, J. Environ. Radioactivity, 138, 106-115, 2014.

Sparholt, H.: Fish species interactions in the Baltic Sea, Dana, 10, 131-162, 1994.

Stohl, A., Seibert, P., Wotawa, G., Arnold, D., Burkhart, J. F., Eckhardt, S., Tapia, C., Vargas, A., and Yasunari, T. J.: Xenon133 and caesium-137 releases into the atmosphere from the Fukushima Dai-ichi nuclear power plant: determination of the source term, atmospheric dispersion, and deposition, Atmos. Chem. Phys., 12, 2313-2343, doi:10.5194/acp-12-2313-2012, 2012.

Tateda, Y.: Development of Basic Model for Dynamic Prediction of ${ }^{137}$ Cs Concentration in Marine Organism. Abiko Research Laboratory CRIEPI Report No. 94056, CRIEPI, Chiba, 57 pp., 1994.

Tateda, Y.: Basic Model for the Prediction of ${ }^{137}$ Cs Concentration in the Organisms of Detritus Food Chain, Abiko Research Laboratory CRIEPI Report, No. 94056, CRIEPI, Chiba, 1997.

Tateda, Y., Tsumune, D., and Tsubono, T.: Simulation of radioactive cesium transfer in the southern Fukushima coastal biota using a dynamic food chain transfer model, J. Environ. Radioactivity, 124, 1-12, 2013.

Tateda, Y., Tsumunem, D., Tsubono, T., Aono, T., Kanda, J., and Ishimaru, T.: Radiocesium biokinetics in olive flounder inhabiting the Fukushima accident-affected Pacific coastal waters of eastern Japan, J. Environ. Radioactivity, 147, 130-141, 2015.

Tateda, Y., Tsumune, D., Tsubono, T., Misumi, K., Misumi, K., Masatoshi, Y., Jota, K., and Ishimaru, T.: Status of ${ }^{137}$ Cs contamination in marine biota along the Pacific coast of eastern Japan derived from a dynamic biological model two years simulation following the Fukushima accident, J. Environ. Radioactivity, 151, 495-501, 2016.
TEPCO (Tokyo Electric Power Company): Current situation of Fukushima Daiichi and Daini nuclear power station, available at: http://www.tepco.co.jp/en/nu/fukushima-np/index-e.html, 2016.

Vives i Batlle, J., Wilson, R. C., and McDonald, P.: Allometric methodology for the calculation of biokinetic parameters for marine biota, Sci. Total Environ., 388, 256-269, 2007.

Vives i Batlle, J.: Dynamic modelling of radionuclide uptake by marine biota: application to the Fukushima nuclear power plant accident, J. Environ. Radioactivity, 151, 502-511, 2016.

Vives i Batlle, J., Beresford, N. A., Beaugelin-Seiller, K., Bezhenar, R., Brown, J., Cheng, J.-J., Ćujić, M., Dragović, S., Duffa, C., Fiévet, B., Hosseini, A., Jung, K. T., Kamboj, S., Keum, D.-K., Kobayashi, T., Kryshev, A., LePoire, D., Maderich, V., Min, B.I., Periañez, R., Sazykina, T., Suh, K.-S., Yu, C., Wang, C., and Heling, R.: Inter-comparison of dynamic models for radionuclide transfer to marine biota in a Fukushima accident scenario, J. Environ. Radioactivity, 153, 31-50, 2016.

Ueda, T., Nakamura, R., and Suzuki, Y.: Comparison of influences of sediments and seawater on accumulation of radionuclides by worms, J. Radiat Res., 18, 84-92, 1977.

Ueda, T., Nakamura, R., and Suzuki, Y.: Comparison of influences of sediments and seawater on accumulation of radionuclides by marine organisms, J. Radiat. Res., 19, 93-99, 1978.

Wada, T., Nemoto, Y., Shimamura, S., Fujita, T., Mizuno, T., Sohtome, T., Kamiyama, K., Morita, T., and Igarashi, S.: Effects of the nuclear disaster on marine products in Fukushima, J. Environ. Radioactivity, 124, 246-254, 2013.

Winterhalter, B., Floden, T., Axberg, S., and Niemisto, L.: Chapter 1. Geology of the Baltic Sea. In: Voipio A. (Editor) The Baltic Sea, Elsevier Oceanography Series, 30, 1-418, 1981.

Yankovich, T., Beresford, N., Wood, M., Aono, T., Anderson, P., Barnett, C. L., Bennett, P., Brown, J. E., Fesenko, S., Fesenko, J., Hosseini, A., Howard, B. J., Johansen, P., Phaneuf, M. M., Tagami, K., Takata, H., Twining, J. R., and Uchida, S.: Wholebody to tissue-specific concentration ratios for use in biota dose assessments for animals, Radiation Environ, Biophysics, 49, 549-565, 2010.

Zhao, X., Wang, W., Yu, K., and Lam, P.: Biomagnification of radiocesium in a marine piscivorous fish, Mar. Ecol. Prog. Ser., 222, 227-237, 2001. 